\title{
Líkami drengsins sem aldrei var til
}

\author{
Um samband samfélags og líkama \\ í óreiðuástandi spænsku veikinnar í Mánasteini \\ eftir Sjón
}

Plágan og borgin eru vel bekktir förunautar í bókmenntum. Frægasta verk plágubókmenntanna, Plágan (La Peste, 1947) eftir Albert Camus, gerist í alsírsku hafnarborginni Oran og hverfist um (skáldaða) útbreiðslu svartadauða innan borgarmúranna. Borgin er sett í sóttkví og ferðir inn og út úr borginni eru með öllu bannaðar. Annað frægt verk í flokki plágubókmennta, Annáll plágunnar (A Journal of the Plague Year, 1722) eftir Daniel Defoe, lýsir útbreiðslu svartadauða í London árið 1665. Sögumaður verksins parf að ákveða hvort hann flýi London og segi par með skilið við fyrirtæki sitt og eignir eða kjósi að dvelja par áfram og eiga bað á hættu að smitast af hinum banvæna sjúkdómi. Nálægð fólks í borginni er mikil og smitleiðir margar. Líkt og bróðir sögumannsins bendir á er „flóttinn besta leiðin til pess að undirbúa sig fyrir pláguna“. ${ }^{1}$ Enn annað og eldra verk sem fjallar um svartadauða er Tídegra (Decameron, 1349-1353) eftir Giovanni Boccaccio. Tíu ungmenni flýja Flórens, sem er undirlögð af svartadauða, og halda til á sveitasetri par sem pau stytta sér stundir við að segja hvert öðru sögur í tíu daga. En pað eru ekki allir sem eiga pess kost að flýja smithættu borga. Hér áður fyrr réð fjárhagsstaða miklu - ef ekki öllu - par um. Hinir ríku áttu mun hægara um vik og pví voru pað hinir fátæku sem dóu unnvörpum í borgum.

Verkin sem hér hafa verið nefnd fjalla öll um svartadauða. En svartidauði er ekki eina farsóttin sem hefur ógnað lífi og heilsu borgarbúa um heim allan heldur hefur fjöldi annarra smitsjúkdóma herjað á borgir heims-

1 „[...] the best preperation for the plague was to run away from it." Daniel Defoe, A Journal of the Plague Year, London: J. M. Dent \& Son Ltd, 1969, bls. 10. 
ins í aldanna rás. ${ }^{2}$ Sá mannskæðasti var inflúensufaraldur, hin svokallaða spænska veiki, sem braust út árið 1918 og er talin hafa lagt yfir fimmtíu milljónir manna í gröfina víða um heim. ${ }^{3}$ Skáldverk sem fjalla um spænsku veikina eru færri en ætla mætti miðað við útbreiðslu farsóttarinnar og pað gríðarlega mannfall sem hún olli. Hér á landi hafa verið skrifaðar tvær skáldsögur sem fjalla um spænsku veikina: Selir eru einfaldir (1920) eftir Gunnar Gunnarsson og Mánasteinn: Drengurinn sem aldrei var til (2013) eftir Sjón. Fræðimenn hafa fjallað um pað að spænska veikin sé eins konar „gleymd veiki“ sökum pagnar sem ríkt hefur um faraldurinn. ${ }^{4}$ Hugsanlegt er að umfjöllun um spænsku veikina hafi fallið í skugga nýafstaðinnar heimsstyrjaldar, einkum vegna takmarkana á fjölmiðlun. ${ }^{5}$ Viggó Ásgeirsson bendir í grein sinni „'Engill dauðans‘: Spænska veikin á Íslandi 1918-1919“ á að sú péttbýlismyndun sem átt hafði sér stað á suðvesturhorni Íslands hafi „skapað áður ópekktar kjöraðstæður fyrir útbreiðslu pessa bráðsmitandi sjúkdóms“. ${ }^{6}$ Viggó telur ástæðuna fyrir pví að smitsjúkdómar valdi jafnan meiri skaða í péttbýli en dreifbýli vera pá að nálægð manna í bæjum og borgum leiði „til stærri smitskammts en stór smitskammtur er líklegri til að valda skæðari sjúkdómi“.7 Veikin gekk yfir í premur bylgjum og var

2 Gerður er greinarmunur á farsótt (e. epidemic) og heimsfaraldri (e. pandemic). Hér á eftir verður pó ekki notast við pessar skilgreiningar heldur munu hugtökin plága, farsótt, faraldur o.s.frv. verða notuð í merkingunni smitsjúkdómur sem breiðist hratt út og hefur stórfelld áhrif á samfélög. Eins verður pláguhugtakið notað yfir hugmyndir og viðhorf sem „smitast“. Siðferðisplágur hafa t.d. sterkan trúarlegan undirtón par sem gefið er í skyn að syndafall gæti átt sér stað ef ákveðin hegðun heldur áfram að breiðast út. Plágur eru nefnilega ekki aðeins sjúkdómar heldur einnig menningarleg smíði. Sjúkdómunum er ljáð merking. Viðbrögð við smitsjúkdómum eru oft úr samhengi við alvarleika peirra og ljóst er að pað hvernig sjúkdómar smitast, á hvaða samfélagshópa peir leggjast og hver einkennin eru hefur mikið að segja um hvaða merking er lögð í sjúkdóminn. Sjá Paul Slack, „Introduction", Epidemics and Ideas: Essays on the Historical Perception of Pestilence, ritstj. Terence Ranger og Paul Slack, Cambridge og New York: Cambridge University Press, 1992, bls. 1-20, hér bls. 8-10.

3 Viggó Ásgeirsson, „'Engill dauðans‘: Spænska veikin á Íslandi 1918-1919“, Saga 46(1)/2008, bls. 76-114, hér bls. 80.

4 Sjá t.d. Catherine Belling, „Overwhelming the Medium: Fiction and the Trauma of Pandemic Influenza in 1918“, Literature and Medicine 28(1)/2009, bls. 55-81, hér bls. 56-57 og Janice Hume, „The „Forgotten“ 1918 Influenza Epidemic and Press Portrayal of Public Anxiety“, FÆMC Quarterly 77(4)/2000, bls. 898-915, hér bls. 899-900.

5 Viggó Ásgeirsson, „’Engill dauðans““, bls. 79.

6 Sama rit, bls. 76.

7 Sama rit, bls. 89. 
pað önnur bylgjan sem dró flesta til dauða. Yfirvöld á Íslandi voru sein að bregðast við annarri bylgju plágunnar pví pau töldu að hún væri af sama meiði og sú fyrsta og pví væg. ${ }^{8}$ Раð varð til pess að spænska veikin breiddist hratt út en blessunarlega tókst að stöðva útbreiðslu farsóttarinnar á Norður- og Austurlandi með pví að staðsetja verði á Holtavörðuheiði og við Jökulsá á Sólheimasandi sem lokuðu umferð. ${ }^{9}$ Pannig var komið í veg fyrir að farsóttin breiddist út um land allt. Talið er að um tveir priðju hlutar íbúa Reykjavíkur hafi smitast af spænsku veikinni ${ }^{10}$ og hátt í fimmhundruð borgarbúa látist úr sjúkdóminum. ${ }^{11}$

Eins og áður sagði fjallar skáldsaga Sjón, Mánasteinn: Drengurinn sem aldrei var til, um innrás spænsku veikinnar í samfélag Reykjavíkur. Mánasteinn segir frá premur viðburðaríkum mánuðum í lífi drengsins Mána Steins haustið 1918. Á pessum stutta tíma gýs Katla, spænska veikin gengur yfir og Ísland öðlast fullveldi frá Dönum. Máni Steinn er sextán ára hinsegin strákur sem elst upp hjá aldraðri langömmusystur frá sex ára aldri eða eftir að móðir hans lést úr holdsveiki. Máni er einrænn, lesblindur, fámáll og hann kýs að fylgjast með úr fjarlægð fremur en taka pátt í félagslífi jafnaldra sinna. Hann eyðir tíma sínum að mestu í kvikmyndahúsum Reykjavíkur, en áhugamálið fjármagnar hann með vændi. Hann unir sér í kvikmyndasalnum par sem hann upplifir ævintýri og hrollvekjur sem hann endurtekur í huga sér, í vöku jafnt sem draumi. Kvikmyndirnar veita honum jafnframt yfirborðspekkingu á mannlegu eðli sem nýtist honum við greiningu á nærumhverfi sínu sem hann sinnir úr hæfilegri fjarlægð.

Máni Steinn er gagntekinn af yfirstéttarstúlkunni Sólu Guðb- sem peysir um bæinn á rauðu mótorhjóli klædd svörtum leðursamfestingi. Hún er jafnframt eina manneskjan, fyrir utan elskendur og viðskiptavini Mána, sem veit að hann er samkynhneigður. Stéttarstaða og kynhneigð Mána Steins skipa honum á jaðar samfélagsins. Hann verður að fara sérstaklega leynt með kynlíf sitt sem hann stundar á afviknum stöðum, oftar en ekki í skiptum fyrir peninga. Pótt Sóla sé af „betri borgurum“ komin hafnar hún einnig pví kynhlutverki sem henni er úthlutað og fer sínar eigin leiðir sem beina henni gjarnan inn á sömu jaðarsvæðin og Máni Steinn tilheyr-

8 Magnús Gottfreðsson, „Spænska veikin 1918: Lærdómur í læknisfræði og sögu“, Laknablaððð 94(11)/2008, bls. 737-745, hér bls. 738.

9 Viggó Ásgeirsson, „'Engill dauðans““, bls. 84.

$10 \quad 15.079$ íbúar voru skráđir til heimilis í Reykjavík.

11 Magnús Gottfreðsson, „Spænska veikin 1918“, bls. 739-740. 
ir. Á meðan Máni er ævinlega jaðarsettur virðist Sóla fær um að ferðast átakalaust á milli miðju og jaðars.

Pegar spænska veikin berst til Reykjavíkur með farbegum skipsins Botníu, sem siglir á milli Danmerkur og Íslands, minnka viðskiptatækifæri Mána enda er sjúkdómurinn bráðsmitandi. Yfirvöld gera lítið úr ástandinu í fyrstu og telja ekki pörf á sóttvörnum. Pegar ljóst er að sjúkdómurinn veldur margfalt meira tjóni en hefðbundin inflúensa er orðið of seint að grípa til aðgerða og yfirvöld í Reykjavík hafa ekki undan að jarða hina látnu. Mána pykir lífið í Reykjavík loksins jafnast á við æsilega atburði kvikmyndanna: „Eitthvert stjórnlaust afl hefur tekið land, eitthvað sögulegt er í pann veginn að gerast í Reykjavík á sama tíma og bað gerist úti í hinni stóru veröld. Hvíta tjaldið hefur rofnað, pað súgar milli heima.“12 Reykjavík verður fljótt að „yfirgefinni sviðsmynd sem hann, Máni Steinn, getur ímyndað sér sem vettvang fyrir hvaða æsilegu atburðarás sem er“. ${ }^{13}$

Í greiningunni sem hér fylgir er leitast við að sýna afbyggjandi áhrif spænsku veikinnar á tvíhyggju og stigveldi. Líkamsorðræða ${ }^{14}$ Mánasteins er skoðuð út frá kenningum Judith Butler, Mary Douglas og Michel Foucault. Par er líkaminn skoðaður sem samnefnari fyrir ýmis afmörkuð fyrirbæri, t.a.m. borgarsamfélagið, og sýnt fram á að ógn við mörk líkamans jafngildir ógn við stöðugleika borgarsamfélagsins. Enn fremur að líkami aðalpersónunnar er á skjön við hugmyndir samfélagsins um hvað telst heilsteyptur og heilbrigður líkami og að samfélagið leitist við að fela eða útrýma slíkum frávikum pví pau afhjúpa rof á menningarmærum pess.

12 Sjón, Mánasteinn: Drengurinn sem aldrei var til, Reykjavík: JPV útgáfa, 2013, bls. 35 .

13 Sama rit, bls. 50.

14 Orðræða er kerfi ályktana (gjarnan nefnt „pekking“) sem tengjast innbyrðis. Orðræða er grunnhugtak í skrifum Michel Foucault. Foucault skilgreindi hugtakið ýtarlega í fyrirlestri sínum „L'ordre du discourse“ (1970). Sjá Michel Foucault, „Skipan orðræðunnar“, Spor í bókmenntafreði 20. aldar: Frá Shklovskí til Foucault, ritstj. Garðar Baldvinsson, Kristín Birgisdóttir og Kristín Viðarsdóttir, pýð. Gunnar Harðarson, Reykjavík: Bókmenntafræðistofnun Háskóla Íslands, 1991, bls. 191-226. Orðræða endurspeglar bæði og mótar samfélagsskipanina, ásamt pví að móta upplifun einstaklinga á samfélaginu. Sjá Adam Jaworski og Nikolas Coupland, „Introduction: Perspectives on Discourse Analysis“, The Discourse Reader, ritstj. Adam Jaworski og Nikolas Coupland, London og New York: Routledge, 2001, bls. 1-44, hér bls. 3 . 


\section{Óreiða líkamans er óreiða samfélagsins}

Mánasteinn fellur ágætlega inn í hefð áðurnefndra plágubókmennta. Plágubókmenntir fjalla í stuttu máli um ógn. Óvæntur sjúkdómur skekur samfélög og umturnar borgarlífi. Samfélagsgerðin riðlast, veraldleg pægindi eru gjarnan úr sögunni og enginn er öruggur í umhverfi sínu. Аð sama skapi birtist í plágubókmenntum á borð við Mánastein líkamsorðræða sem afbyggir hugmyndir um hinn heilbrigða líkama. Sjúkdómar breyta ásýnd og starfsemi líkamans. Hugmyndin um hinn heilbrigða líkama er líkamsímynd sem erfitt er að holdgera að fullu en allir eiga pó að stefna að. Samkvæmt kenningu Foucault um alsæishyggju sem hann setti fram í Geslu og refsingu (Surveiller et punir) búum við í eftirlitssamfélagi par sem eftirlit með líkömum okkar fer ekki aðeins fram innan ákveðinna stofnana heldur sér samfélagið allt um að framkvæma eftirlitið og refsa peim sem gerast brotlegir. Valdbeitingin kemur innan frá - frá einstaklingnum sjálfum sem upplifir sig undir stöðugu eftirliti. Eftirlitið miðar m.a. að pví að innræta einstaklingum hugmyndir um „eðlilega“ líkamshegðun og refsa peim sem brjóta gegn peim hugmyndum með hegðun sinni. Valdið leitast við að aga eða fela pá líkama sem eru á skjön við líkamsímyndina svo óraunsæi staðalmyndarinnar verði ekki afhjúpað. ${ }^{15}$

Í Mánasteini er óstöðugleiki líkamans afhjúpaður pegar spænska veikin heltekur líkamann og samfélag Reykjavíkur. Aðgreining heilbrigðra og smitaðra purrkast út og líkaminn verður vettvangur par sem ósættanlegar andstæður renna saman. Veikin færir vessa upp á yfirborðið svo að aðgreining hins innra og hins ytra verður óljós og líkaminn verður brotakenndur og opinn. Áður en hægt er að skoða hver afbyggjandi virkni spænsku veikinnar er í verkinu er gagnlegt að greina nánar frá póststrúktúralískum kenningum um líkamann. ${ }^{16}$

Bandaríski heimspekingurinn Judith Butler hefur sýnt fram á að hinn kynjaði líkami er skilgreindur og mótaður í menningunni og að kyngervi hafi lítið með líffræðilegt kyn að gera. Samkvæmt Butler (og fjölda annarra femínista) grundvallast líkamsorðræða á andstæðuhugsun og er birting-

15 Michel Foucault, „Alsæishyggja“, Alsei, vald og pekking, ritstj. Garðar Baldvinsson, pýð. Björn Porsteinsson, Reykjavík: Bókmenntafræðistofnun Háskóla Íslands, 2005, bls. 129-169, hér bls. 139-140 og 145-146.

16 Líkaminn í póststrúktúralískum skilningi er menningarafurð sem verður að skoða á forsendum tungumálsins par sem öll pekkingarsköpun á sér stað. Engin hugsun er til sem ekki er bundin í tákn og pví er ekki hægt að skoða líkamann nema út frá stöðu hans sem tákns í táknkerfi menningar. 
armynd félagslegs forræðis. ${ }^{17}$ Andstæðupör (e. binary oppositions) eru sögð náttúrleg en vísa í raun aðeins í önnur andstæðupör svo úr verður kerfi sem byggir á engu öðru en sjálfu sér. Samkvæmt Butler eru hverskonar rof á mörkum líkamans ógn við petta kerfi pví pau sýna líkamann sem brotakenndan og opinn en ekki stöðugan og lokaðan líkt og sjálfsmynd okkar byggir á. ${ }^{18}$ Grundvallarkenning Butlers er að kyngervi (e. gender) sé gjörningur (e. performance). Hana kynnti hún ítarlega í bók sinni Kynusli (Gender Trouble). Par sýnir hún fram á að kyngervi er ekki náttúrulegt heldur sé stöðugt verið að framleiða раð og endurframleiða раð með merkingarbærum gjörðum og í tungumálinu með svokölluðum ítrekandi yrðingarathöfnum (e. locutionary acts). ${ }^{19}$ Butler telur jafnframt að hinn kynjaði líkami hafi enga verufræðilega stöðu (e. ontological status) aðra en pær merkingabæru gjörðir sem einstaklingurinn framkvæmir til pess að staðfesta og viðhalda kyngervi sínu. ${ }^{20}$ Par með er ljóst að líkaminn, líkt og kyngervi, er menningarleg smíði.

Breski mannfræðingurinn Mary Douglas setti fram pá kenningu í bók sinni Hreinleiki og hetta (Purity and Danger) að pað megi finna beina tengingu á milli líkamlegra landamæra og markalína menningarsamfélaga pví líkaminn sé í raun hlutgerving hinnar félagslegu heildar: „Líkaminn er líkan sem getur táknað hvaða afmarkaða kerfi sem er. Mörk líkamans geta

Judith Butler, Gender Trouble: Feminism and the Subversion of Identity, New York og London: Routledge, 2006 [1990], bls. 175-176.

18 Sama rit, bls. 182.

19 Locutionary act (yrðingarathöfn í pýðingu Vilborgar Sigurðardóttur: Judith Butler, „Monique Wittig: Upplausn líkamans og uppspunið kyn“, pýð. Vilborg Sigurðardóttir, Jón Ólafsson ritaði inngang, Ritið 2/2002, bls. 161-184, hér bls. 168) er hugtak John L. Austin. Prír pættir eru í málathöfn: yrðingarathöfn (e. locutionary act), yrðingarframkvæmd (e. illocutionary act) og yrðingarviðbragð (e. perlocutionary act). Sjá John L. Austin, How to Do Things with Words, London: Oxford University Press, 1965, bls. 108. Butler segist í viðtali pó ekki hafa verið meðvitað að vinna með kenningar Austins í Gender Trouble, heldur hafi hún verið að vinna með Derrida sem hafi notað kenningar Austins. Sjá Vikki Bell, „On Speech, Race and Melancholia: An Interview with Judith Butler", Theory, Culture and Society 16(2)/1999, bls. 163-174, hér bls. 164-165. Í grein sem hún skrifaði fyrir útgáfu Gender Trouble notast hún við talathafnakenningu Johns Searle, sem aftur byggir á Austin. Sjá Judith Butler, „Performative Acts and Gender Constitutions: An Essay in Phenomenology and Feminist Theory“, Theatre Fournal 40(4)/1988, bls. 519-531, hér bls. 519. Butler notar síðar kenningar Austins í bókinni Excitable Speech. A Politics of the Performative, London og New York: Routledge, 1997.

20 Judith Butler, Gender Trouble, bls. 185. 
staðið fyrir sérhverja markalínu sem er ógnað eða er óstöðug.“21 Мeð pví að hafa eftirlit með líkömum einstaklinga gætir samfélagið pess að engin ógn steðji að peim mörkum sem samfélagið byggir sjálfsmynd sína á. ${ }^{22}$ Douglas telur að hverskyns formgerðir (e. structures) séu viðkvæmar á jöðrunum og pví purfi að tryggja að ekkert ógni stöðugleika mæranna sem aðskilur formið frá umhverfi pess. ${ }^{23}$ Allar heildir eru mótaðar með skýrt afmörkuðum mærum og pví setur óstöðugleiki á mörkunum heildina í hættu. Hún nefnir petta „hættuástand“ félagslega mengun (e. social pollution) og tiltekur fjórar gerðir hennar: Fyrsta mengunarhættan felst í utanaðkomandi ógn sem prýstir á mörk afmarkaða svæðisins, önnur hætta kemur innan frá og ógnar innri mörkum heildarinnar, priðja á sér stað á sjálfum mörkunum og fjórða er hverskyns ósamræmi sem ógnar einingu heildarinnar. ${ }^{24}$ Séu mærin færð til eða rofin brenglast formið pannig að til verður nýtt/annað fyrirbæri. Douglas sýnir fram á pað með fjölmörgum dæmum að hættusvæði líkamans eru mismunandi í ólíkum menningarsamfélögum og pví ljóst að mörk líkamans eru tilbúin og mótuð af menningu hvers samfélags: „Hvert menningarsvæði hefur sínar hættur og sín vandamál. Hvaða ákveðnu líkamsmörk trúarkenningar hvers svæðis telja valdamikil veltur á pví hvaða aðstæður líkaminn speglar.“25

Líkami Mána er átakasvæði sem endurspeglar á margan hátt formgerð samfélagsins sem hann er hluti af. Í honum skarast margskonar félagslegar sýkingar sem ógna hugmyndinni um hreinleika samfélagsins. Fyrir pað fyrsta er hann sonur holdsveikrar konu, svo er hann samkynhneigður auk pess að vera virkur neytandi erlendrar afpreyingar sem er fær um að „smita“ áhorfandann af nýstárlegum hugmyndum. Meintur hreinleiki íslenska samfélagsins felst að hluta í fábreytni pess, hversu afskekkt og einangrað pað er og samfélagið einsleitt. Рað mætti pví segja að samfélagið sem myndaðist á Íslandi hafi haft meira afgerandi menningarmæri en peir menningarheimar sem voru í návígi við aðra menningarheima. Samkvæmt

21 „The body is a model which can stand for any bounded system. Its boundaries can represent any boundaries which are threatened or precarious." Mary Douglas, Purity and Danger: An Analysis of Concept of Pollution and Taboo, London og New York: Routledge, 2002 [1966], bls. 142.

22 Sama rit, bls. 141-152.

23 Sama rit, bls. 141-142 og 149-151.

24 Sama rit, bls. 151-152.

25 „Each culture has its own special risks and problems. To which particular bodily margins its beliefs attribute power depends on what situation the body is mirroring." Sama rit, bls. 150. 
kenningum Douglas kalla skýr menningarmæri tiltekins samfélags á að mæri líkamans séu par jafn afgerandi. Líkami Mána er félagslega mengandi pví hann skapar ósamræmi innan formgerðarinnar og ógnar pannig einingu heildarinnar. En pegar plága nemur land riðlar hún viðteknum stigveldum og menningarmærum á meðan hún varir og sýkir samfélagið svo að pað missir aðgreiningarmátt sinn. Hér á eftir verður skoðað nánar hvernig Máni Steinn setur pessi líkamsmæri í hættu og hvernig spænska veikin sundrar hugmyndum um heilbrigðan líkama og par með hreinleika samfélagsins.

\section{Smitandi kynvilla}

Eins og áður segir gerist sagan haustið 1918 pegar samkynhneigð var enn ólögleg á Íslandi. ${ }^{26}$ Kynlíf fólks af sama kyni er ógn við hugmyndina um hinn náttúrulega og stöðuga líkama. Butler bendir á að: „Par sem endaparms- og munnmök milli karlmanna staðfesta greinilega ákveðnar tegundir líkamlegs gljúpleika sem ráðandi fyrirkomulag heimilar ekki er litið á samkynhneigð karla, innan hins ráðandi sjónarhorns, sem vettvang hættu og mengunar [...].“27 Líkamar samkynhneigðra eru undir strangara eftirliti en líkamar gagnkynhneigðra og má segja að peir sé í nokkurskonar félagslegri gíslingu. Líkaminn tilheyrir ekki einstaklingnum sem lifir í honum heldur samfélaginu sem skilgreinir hann og stjórnar honum. Líkt og Michel Foucault sýndi fram á í bókarkaflanum „Bælingartilgátunni“ ${ }^{28}$ pá varð samkynhneigði einstaklingurinn í raun ekki til fyrr en á 19. öld: „Á 19. öld er hinn samkynhneigði orðinn að sérstakri persónu sem á sér fortíð, sögu, bernsku, skapgerð, lífsmáta. [...] Kynhneigðin nær til allra sviða tilveru hans. [...] Sódómistinn er talinn hafa hrasað, en sá samkynhneigði er tegund út af fyrir sig.“29 Áður var talað um sódómskan verknað

26 178. grein almennra hegningarlaga. Lögin voru í gildi frá árinu 1869 til 1940. Sjá t.d. Linda Fanney Valgeirsdóttir, „Réttarstaða samkynhneigðra: skref fyrir skref“, MA-ritgerð í lögfræði við Háskóla Íslands, 2010, bls. 21, aðgengileg á vefnum Skemman: http://hdl.handle.net/1946/4922.

27 „Since anal and oral sex among men clearly establishes certain kinds of bodily permeabilities unsanctioned by the hegemonic order, male homosexuality would, within such a hegemonic point of view, constitute a site of danger and pollution [...]." Judith Butler, Gender Trouble, bls. 180.

28 Kaflinn er hluti af fyrsta bindi Histoire de la sexualité: La Volonté de savoir (1976).

29 Michel Foucault, „Bælingartilgátan“, Alsei, vald og pekking, ritstj. Garðar Baldvinsson, pýð. Björn Porsteinsson, Reykjavík: Bókmenntafræðistofnun Háskóla Íslands, 2005, bls. 180-211, hér bls. 204-205. 
en með blætisvæðingu kynlífsins var farið að innlima kynhegðun í persónu manneskjunnar. Öll ævi manneskjunnar var vitnisburður um innra eðli - afhjúpandi hegðun sem purfti að greina og refsa fyrir. Í ritdómi um Mánastein bendir Ásta Kristín Benediktsdóttir á að íslensk lög á peim tíma hafi einfaldlega bannað „samræði gegn náttúrulegu eðli“ án pess að tiltaka hvað væri náttúrulegt eðli og hvað ekki. Að hennar mati hefur ríkt pöggun um samkynhneigð á Íslandi á fyrri hluta 20. aldar og undirtitill skáldsögunnar, Drengurinn sem aldrei var til, endurspegli ósýnileika samkynhneigðra í íslenskri (bókmennta)sögu. ${ }^{30}$

Í verki Sjón birtist læknirinn Garibaldi sem málpípa pessarar orðræðu um „kynferðislega afbrigðileika“ sem Foucault telur hafa komið fram undir lok 19. aldar. ${ }^{31}$ Garibaldi telur samkynhneigð vera ákveðna hnignun sem erlend áhrif hafi orsakað og eru par kvikmyndir fremstar í flokki spillandi áhrifa: „[...] Tilgáta mín ... varnaðarorð ... menn verða næmari fyrir bomosexualiteti við kvikmyndagláp ...".32 Athyglisvert er að af orðum Garibalda að dæma er hann ekki peirrar skoðunar að kynhneigð sé meðfædd heldur að hver sem er sé fær um eða eigi á hættu að „smitast“ af henni. Lesa má úr textanum, sem hann birtir í tímaritinu Landinu ${ }^{33}$ tveimur árum áđur en hann sannfærist „um pátt kvikmyndahúsanna í útbreiðslu pestarinnar“, ${ }^{3}$ ótta um að gagnkynhneigður einstaklingur geti orðið samkynhneigður við pað eitt að horfa ítrekað á „naktar axlir Thedu Bara, munúðarfull augnlok Pín Menichelli, [...] sterklegar fingurneglur Gunnars Tolness, stinn leri Douglas Fairbanks eða blið augu Max Linders“ og telur hann áhrif nærmyndanna slík „að festir megna að verjast peim“. ${ }^{35}$ Samkynhneigð er sett fram sem afbrigðileg kynhegðun sem orsakast af peirri hlutgervingu á líkömum leikaranna sem Garibaldi telur að eigi sér stað á kvikmyndatjaldinu. Hann líkir áhorfandanum við líkskurðarmeistara sem horfir á „hlutina“ á tjaldinu og hamflettir pá með augunum svo að beinin blasa við. Garibaldi er greinilega lærður í blætisfræðum sálgreiningarinnar pví honum er tungu-

30 Ásta Kristín Benediktsdóttir, „Kynvilla á dögum spænsku veikinnar“, Spássía 4/2013, bls. 6 .

31 Michel Foucault, „Bælingartilgátan“, bls. 193.

32 Sjón, Mánasteinn, bls. 109. Skáletrun upprunaleg.

33 Tímaritið Landið var vissulega til og gefið út á árunum 1916-1918 en greinin „Kvikmyndir og sálarmein“ sem sögupersónan Garibaldi er sagður hafa birt par er skáldskapur.

34 Sjón, Mánasteinn, bls. 89.

35 Sama rit, bls. 91. Skáletrun upprunaleg. 
málið tamt: ${ }^{36}$ „Kvikmyndin er pví ósiðleg i eðli sínu, bún ummyndar leikarann i fetish og kallar fram pervertion i áborfandanum sem letur telast af henni eins og fiðrildi af eldsloganum. “37 Kvikmyndahúsið er vettvangur tvennskonar smits í huga læknisins (og valdsins): Kynvillu og spænsku veikinnar. Af öllum peim félagslegu mengunarhættum sem Douglas nefnir er auðveldast að takast á við hættuna sem kemur að utan. Рað skal pví ekki undra að Garibaldi afneiti uppruna „sjúkleikanna“ og skelli skuldinni á kvikmyndahúsið sem í hans huga er uppspretta siðferðislegrar hnignunar. Pannig má halda pví fram að ónáttúruna sé ekki að finna innan íslensks pjóðfélags heldur sé hún ættuð erlendis frá og að smitberinn sé hin nýja kvikmyndatækni.

\section{Likamanum sundrað}

Pegar spænska veikin berst til Íslands höfðu Íslendingar staðið í áratuga langri baráttu fyrir sjálfstæði frá Dönum og hluti peirrar baráttu fólst í ímyndarsköpun íslensku pjóðarinnar par sem hreinleika og dug var teflt fram sem helstu einkennismerkjum hennar. Hvorki spænska veikin né „kynvilla“ samræmist pessum pjóðernishugmyndum: „Og einnig heyrist að ekki sé mark á pví takandi pótt Danskurinn kveinki sér, önnur lögmál gildi um hann en íslenska afkomendur Egils Skallagrímssonar. “38 Рað verður bó fljótt ljóst að pessi hetjuímynd á ekki við rök að styðjast, pví Íslendingar veiktust og dóu úr veikinni rétt eins og aðrir íbúar Evrópu. Sigríður Matthíasdóttir telur að pjóðernisleg sjálfsmynd Íslendinga í sjálfstæðisbaráttunni hafi grundvallast á útilokun ákveðinna hópa með pað fyrir augum að skapa heilsteypta en um leið einsleita sjálfsmynd. Hún segir að pjóðernisstefna Íslendinga hafi byggst á stöðluðum karlmennskuímyndum

36 Einnig má greina skýr textatengsl við fræga grein Lauru Mulvey „Visual Pleasure and Narrative Cinema“ (1973) sem byggir einmitt á kenningum Freuds um glápið: „Að sama skapi kallast hefðbundnar nærmyndir af fótleggjum (Dietrich er gott dæmi) eða andliti (Garbo) á annarskonar kynferðislega upplifun. Nærmynd af líkamshluta truflar pá hefðbundnu rýmisskynjun sem frásögnin krefst. Hún upprætir dýptarskynjunina, fletur út myndina og skapar tilfinningu fyrir klippimynd eða 1́koni fremur en rými.“ Laura Mulvey, „Sjónræn nautn og frásagnarkvikmyndin“, Áfangar i kvikmyndafreðum, ritstj. Guðni Elísson, pýð. Heiða Jóhannsdóttir, bls. 330-341, hér bls. 335.

37 Sjón, Mánasteinn, bls. 91. Skáletrun upprunaleg.

38 Sama rit, bls. 33. 
sem vísuðu í hugmyndir um hina svokölluðu gullöld Íslands (pjóðveldistímann) til pess að styrkja stöðu Íslendinga í sjálfstæðisbaráttunni. ${ }^{39}$

Máni Steinn er ekki hluti af peim forréttindahópi sem íslenska sjálfsmyndin hampar. Pvert á móti er hann ógn við pessa brothættu sjálfsmynd pví samkynhneigð samræmist ekki stöðluðum karlmennskuímyndum. Pegar hann er gripinn í ástarleik með dönskum sjóliða (og pað á sjálfan fullveldisdaginn) grípur um sig mikill ótti hjá fyrirmönnum Reykjavíkur.

Landið yrði að athlægi í Danmörku, andstæðingar hins nýja fullveldis myndu hafa pað að háði og spotti á pann meinlega máta sem Dönum einum er lagið, og segja eins gott að peir hefðu losað sig við pessa pjóð attaníossa sem gæti ekki séð danska sjóliða í friði - og mundu peir ekki uppnefna landið Attanossía og velja pví klúran fána til háðungar? ${ }^{40}$

Forréttindastéttin óttast að líkami samkynhneigðs unglings verði gerður að táknmynd íslensku pjóðarinnar. „Ғað síðasta sem menn vilja sjá á pessum árdögum hins fullvalda Íslands eru fyrirsagnir um reykvískt kynvillingahneyksli í innlendum dagblöðum og dönskum. “41 Sjálfstæðissinnaðir menntamenn höfðu haft mikið fyrir pví að sýna fram á að Íslendingar væru stignir upp úr pví niðurlægingartímabili sem hafði varað síðan Íslendingar gengu Noregskonungi á hönd og par með endurheimt sitt upprunalega „sjálf“. 42 Til pess að hindra að „ský erlendrar ónáttúru“ dragi fyrir „pá yljandi sól sem reis í döprum hjörtum pjóðarinnar" á fullveldisdegi hennar sættast fyrirmennin á að senda Mána Stein úr landi. ${ }^{43}$ Par veita peir Mána nokkurs konar frelsi frá peirri jaðarsetningu sem hann býr við á Íslandi.

Ljóst er að pjóðernisleg sjálfsmynd Íslendinga polir ekki ósamræmið sem tilvist Mána skapar og pví er hann óhjákvæmilegur útlagi samfélagsins. Honum tekst lengi vel að halda sig úr sjónmáli valdsins með pví að dvelja á jaðri samfélagsins og forðast samskipti við jafnaldra sína, en pegar hann er gripinn með sjóliðanum á merkisdegi sjálfstæðisbaráttunnar verð-

39 Sigríður Matthíasdóttir, „Pjóðerni og karlmennska á Íslandi við upphaf 20. aldar“, Pjóðerni i púsund ár?, ritstj. Jón Yngvi Jóhannson, Kolbeinn Óttarsson Proppé og Sverrir Jakobsson, Reykjavík: Háskólaútgáfan, 2003, bls. 119-132, hér bls. 119-121.

40 Sjón, Mánasteinn, bls. 108. Skáletrun upprunaleg.

41 Sama rit, bls. 108.

42 Sigríður Matthíasdóttir, „Pjóðerni og karlmennska“, bls. 102.

43 Sjón, Mánasteinn, bls. 108. 
ur hann að augljósu fráviki sem valdið parf að leiðrétta til pess að viðhalda heilsteyptri sjálfsmynd sinni. Hann er eins og vessar líkamans sem Douglas segir að eigi aldrei afturkvæmt í líkamann: „Рað sem fer úr líkamanum má aldrei snúa pangað aftur og pað ber að forðast. Hættulegasta mengunin eru líkamsvessar sem fá aftur inngöngu í líkamann. “44 Douglas telur líkamsop vera sérstaklega viðkvæm svæði bví pau hleypa vessum úr líkamanum sem rjúfa par með mörk líkamans. ${ }^{45}$ Butler vinnur áfram með pessar kenningar Douglas og sýnir fram á að neikvætt viðhorf í garð líkamsvessa eigi rót sína í hugmyndinni um líkamann sem heild sem hafi skýrt afmarkaðar útlínur og fast form. Vessar eru til marks um að svo sé ekki heldur að líkaminn sé í raun hriplekur. Líkamsop eru pví talin vera sérstaklega hættuleg svæði sem parfnast eftirlits, tilgangur peirra er pröngt skilgreindur og öll notkun sem samræmist ekki skilgreiningum er sögð vera afbrigðileg og beinlínis hættuleg. ${ }^{46}$

Spænska veikin er sjúkdómur sem færir blóð og aðra vessa upp á yfirborðið og rýfur par með mærin sem aðskilja innri líkamsstarfsemi frá yfirborði líkamans. Einkennunum er lýst með eftirfarandi hætti í Mánasteini:

Einkenni „spönsku veikinnar“ eru pessi: Ákafur hiti [...] höfuðverkur, eyrnabólgur, særindi í hálsi og fyrir brjósti, purr hósti sem endar með slímkenndum uppgangi, gulleitum eða blóðblönduðum, prautir í vöðvum og liðum, niðurgangur. Blóðnasir eru tíðar [...] En blóðið fossar ekki aðeins úr nösunum, heldur streymir pað úr eyrum og tannholdi, upp úr lungum og maga, niður úr pörmum og gegnum pvagrásina. $^{47}$

Pegar Máni Steinn veikist af spænsku veikinni taka að birtast óráðskenndar senur; í einni peirra er hann smám saman rændur líkamspörtum sínum af svartklæddri veru og í annarri blæðir honum af svo miklum krafti að hann parf að ösla eigin blóðflaum. Að lokum ákveður hann að hann parfnist ekki líkamans og tekur að sundra honum með pví að breyta föstu efni í fljótandi og láta pað „fossa um öll op sem hann finnur“. 48 Óráðsdraumarnir

44 „Anything issuing from the body is never to be re-admitted, but strictly avoided. The most dangerous pollution is for anything which has once emerged gaining re-entry." Mary Douglas, Purity and Danger, bls. 152.

45 Sama rit, bls. 150.

46 Judith Butler, Gender Trouble, bls. 180-181.

47 Sjón, Mánasteinn, bls. 84.

48 Sama rit, bls. 65. 
virðast endurspegla framgang sjúkdómsins og pað má greina breytingu á andrúmslofti peirra pegar Mána byrjar að blæða. Hryllingurinn hverfur og við tekur falleg sviðsmynd af fjöru baðaðri sumarbleiku sólskini. Blóð hans rennur viðstöðulaust og teiknar á hann yfirvaraskegg, undirstrikar augun og skreytir eyrnasnepla hans „eins og línur dregnar af meistarahendi““49 Pvottakonur staðarins eru pó ekki jafn hrifnar af blóðrákunum, segja „[u]ss, sjáið hvað hann er búinn að skíta sig út!“ og stinga honum ofan í pvottabala og skrúbba par til „hann er orðinn mjúkur sem lín“ “50 Pær reyna að pvo ummerkin en tekst ekki ætlunarverkið pví Máni tekur sjálfur völdin og segir skilið við hugmyndir peirra um hreina líkamann með pví að leysa hann upp: „Drengurinn parfnast ekki lengur blóðs og beina, hvorki vöðva né innyfla. Hann sundrar líkama sínum, breytir föstu efni í fljótandi, byrjar innan frá og skolar pví út, lætur pað fossa um öll op sem hann finnur."

Draumarnir sem Mána dreymir áđur en hann veikist snúast einnig um sundrung líkamans, sem túlka má sem löngun til að brjóta af sér kirfilega skilgreind menningarmæri líkamans. Hann dreymir að höfuð hans hafi verið aflimað og falið í kistli á bak við málverk. ${ }^{52}$ Líkaminn stendur hins vegar spariklæddur við fótagafl rúms sem tilheyrir einum af vændiskaupendum hans. Maðurinn tekur höfuð Mána, leggur pað við hlið sér og breiðir upp að höku svo að líkamsleysið er hulið. ${ }^{53}$ Sjónhverfingin lætur hinn kynferðislega afbrigðilega líkama hverfa og birtast annars staðar, uppábúinn sem annar og fínni líkami. „Kóninn“ í draumnum er maður sem Máni veitti munngælur fyrr um kvöldið undir kletti í Öskjuhlíð. Pessi ónefndi maður er fullur sjálfshaturs vegna kynhneigðar sinnar sem sést glögglega á framkomu hans í garð Mána síðar í verkinu. Eftir að Máni er gripinn 1 ástarleiknum með danska sjóliðanum er hann lokaður inni á meðan ákvörðun er tekin um hvað skuli gera við „kynvillinginn“. Par hefur kóninn hæst og talar um að „slá hann af“ og fela líkið ${ }^{54}$ - með öðrum

49 Sama rit, bls. 63.

50 Sama rit, bls. 64.

51 Sama rit, bls. 65 .

52 Draumurinn kallast á við atriði í kvikmyndinni Blóðsugunum (1915) (f. Les Vampires), eftir Louis Feuillade, sem Máni Steinn heldur mikið upp á. Aðalpersóna myndarinnar er blaðamaðurinn Philipe Guérande sem finnur aflimað höfuð rannsóknarlögreglumanns í kistli á bak við málverk við rannsókn sína á Blóðsuguglæpagenginu.

53 Sjón, Mánasteinn, bls. 17.

54 Sama rit, bls. 107. 
orðum koma Mána fyrir kattarnef áđur en honum gefst tækifæri á að ljóstra upp leyndarmáli kónans.

Draumurinn er einnig áhugaverður í ljósi pess að höfuð Mána er geymt (eins og falinn fjársjóður) á bak við málverk af sveitabænum sem hann ólst upp á til fimm ára aldurs. Minningar hans frá uppvextinum á sveitabænum eru bundnar við hurðina sem skildi hann og móður hans að. Móðir Mána var sjúk af holdsveiki ${ }^{55}$ og fékk aldrei að hafa Mána Stein hjá sér. Samskipti peirra áttu sér stað í gegnum lúgu á hurðinni og huldi hún pá jafnan húð sína með blæju og hönskum. Máni fær eitt sinn að horfa á hana óhulda í gegnum glasbotn sem mildar útlínur andlits hennar en annars fær hann aldrei að sjá hana með berum augum. Móðir Mána er lokuð inni til pess að koma í veg fyrir smit og vegna pess að líkami hennar fellur ekki að fegurðarstöðlum samfélagsins. Dagný Kristjánsdóttir bendir á í grein sinni „Mánasteinn í grimmdarleikhúsi spænsku veikinnar“ að viðhorf kirkjunnar til holdsveikra hefur í gegnum aldirnar verið pversagnarkennt. Holdsveikir voru sagðir syndarar og holdsveikin refsing Guðs. İ Biblíunni er pví fyrirskipað að líkami holdsveikra skuli vera bæði auðkennanlegur (hulinn rifnum klæðum, óhirtu hári o.s.frv.) og úr augsýn: ${ }^{56}$ „Hinir holdsveiku báru sekt sína utan á sér. “57 Líkami hins sjúka er ekki viðurkenndur í samfélaginu og pví parf að koma honum úr augsýn, hylja hann með blæju eða gera hann óskýran í augsýn peirra sem teljast heilbrigðir.

Pegar móðir Mána fellur frá var honum komið fyrir á Holdsveikraspítalanum í Laugarnesi. Par var gengið úr skugga um að hann væri ekki sýktur af holdsveiki og hann sendur í fóstur til langömmusystur sinnar eftir ársdvöl á spítalanum. Prátt fyrir að vera dæmdur hæfur til pess að lifa í samfélaginu pá virðist hann upplifa sig sem afbrigðilegan eða sjúkan í einsleitu samfélagi heilbrigðra. Pegar spænska veikin tekur síðar land á Íslandi samræmist ástandið í samfélaginu loksins ,innra lífi“ hans. ${ }^{58}$

55 Holdsveiki er bakteríusýking sem herjar á taugavefi blóðminni svæða líkamans og brýtur pau niður; líkamanum er ekki sundrað innan frá heldur rotna útlimir lifandi líkamans. Holdsveiki er pví hálfgerður mannáts-sjúkdómur pví bakteríurnar brjóta niður hold sjúklingsins á meðan hann er enn á lífi. Sjá Erla Dóris Halldórsdóttir, Holdsveiki á Íslandi, Reykjavík: Mál og mynd, 2001, bls. 31-36. Annað orð yfir holdsveiki er líkprá og endurspeglar bað rotnunarvirkni sjúkdómsins sem breytir líkamanum smám saman í lík.

56 Dagný Kristjánsdóttir, „Mánasteinn í grimmdarleikhúsi spænsku veikinnar“, Skírnir 189(haust)/2015, bls. 474-490, hér bls. 479-480.

57 Sama rit, bls. 480.

58 Sjón, Mánasteinn, bls. 85. 
Pegar Máni brýtur gegn reglum samfélagsins og afbyggir menningarmæri líkamans eða pegar spænska veikin heltekur samfélagið svo að ekki er lengur hægt að gera skýran greinarmun á „heilbrigðum“ og „sjúkum“ ólmast svart fiðrildi í brjósti Mána sem blakar vængjum sínum ótt og títt: „Hann er með fiðrildi í brjóstinu, svipað pví sem hann fær pegar hann tekur „kóna“ á löpp, nema að pað er stærra, vænghaf pess meira, liturinn svartur sem flauelsborðar líkvagnsins. “59 Fiðrildið60 ${ }^{61}$ blar vængjum sínum pegar Máni Steinn gerir eða upplifir hluti par sem spenna myndast á mörkum menningarlega líkamans. ${ }^{61}$ Pegar hann leysist síðan algjörlega upp í síðasta kafla bókarinnar er ekkert eftir nema svarta fiðrildið: „[...] hann verður allt í einu skelfilega léttur á sér. Hann lítur á hendur sínar og horfir í gegnum pær. Hann preifar eftir búknum en grípur í tómt. Hann finnur ekki fyrir neinu nema vængjaslætti par sem hjarta hans var áđur.“62 Máni er steinsnar frá Holdsveikraspítalanum pegar hann leysist upp. Holdsveikraspítalinn er táknmynd sjúkleikans sem Mána var sagt að paga yfir - að snúa pangað aftur skapar mengunarhættu á borð við pá sem skapast ef vessar líkamans snúa aftur í líkamann sem kastaði peim út. Líkaminn hverfur en sjálfið heldur áfram að flögra á sviðum par sem menningarmæri líkamans eru véfengd og skjönuð.

\section{Tvífararnir Máni og Sóla}

Máni Steinn á tvífarann Sólborgu Guðbjörnsdóttur sem Máni kallar ekki annað en Sólu Guðb-. Sóla og Máni eru ekki andstæður heldur hliðstæður, hvort í sínum heimi; hún er hluti af heimi góðborgara Reykjavíkur en hann er á jaðrinum. Máni Steinn er með Sólu á heilanum og segist vita

59 Sama rit, bls. 35 .

60 Gríska orðið yfir fiðrildi er pað sama og yfir sál (gr. psyche) og er persónan Psyche í grískri goðafræði gjarnan sýnd sem fiðrildi. Sjá Britannica Academic, „Psyche“, sótt 15. mars 2018 af http://academic.eb.com/levels/collegiate/article/Psyche/61713. Fiðrildi eru einnig lífverur sem myndbreytast; pær hefja lífshlaup sitt sem lirfa sem síðan býr sér til púpu par sem hún breytir um mynd og skríður úr púpunni sem fullvaxta fiðrildi. Fiðrildi eru pví hentug myndlíking fyrir hugmyndina um líf sálarinnar eftir líkamlegan dauða; lirfan táknar lífið, púpan dauðann og fiðrildið líf sálarinnar eftir dauðann.

61 Eins má benda á að í spænskumælandi löndum er hugtakið fiðrildi (s. mariposa) notað sem slanguryrði yfir samkynhneigða menn, pá með karlkynsendingu -o í stað kvenkynsendingarinnar -a: mariposo. Slangrið er almennt talið niðrandi, pótt hugsanlegt sé að pað hafi verið endurheimt (e. reclaimed) af samkynhneigðum á sama hátt og ýmis önnur hugök sem áður voru talin niðrandi (t.d. queer).

62 Sjón, Mánasteinn, bls. 127. 
allt um hana pótt hún viti lítið annað um hann en að hann „pjónustar kóna“ í Öskjuhlíð. Hann tekur fyrst eftir henni á sýningu á kvikmyndinni Blóðsugunum, eftir Louis Feuillade, pegar hún stendur upp til að yfirgefa kvikmyndasalinn: „Augnablikið sem skuggi hennar féll á sýningartjaldið runnu pær saman, hún og persónan í kvikmyndinni. Hún leit við og geislinn varpaði andliti Musidoru á andlit hennar. “63 Persónan sem leikkonan Musidora túlkar er Irma Vep, en nafnið er stafarugl fyrir orðið Vampire. Sóla Guðb- er samskonar stafarugl fyrir orðið Blóðsuga og undirstrikar nafnaleikurinn pá sterku tengingu á milli kvenpersónanna sem Máni skapar í huga sér. Eins og áđur hefur komið fram er Máni forfallinn kvikmyndaunnandi. Hann sér hverja einustu mynd sem sýnd er í kvikmyndahúsunum tveimur sem starfrækt eru í Reykjavík. Vegna lesblindu hefur Máni flosnað upp úr námi en í staðinn notar hann kvikmyndir til pess að fræðast um mannleg samskipti og túlka umhverfi sitt:

Hann skemmtir sér við að greina mannlífið af peirri skyggni sem hann hefur öðlast við að horfa á hálft púsund bíómynda par sem hvert augnatillit, hver einasta hreyfing, hver svipur og hver líkamsstaða eru hlaðin merkingu og vísbendingum um innri líðan og fyrirætlan, bæði góða og illa. Já, öll hegðun mannskepnunnar er honum sem opin bók [...]. ${ }^{64}$

Máni sér heiminn í gegnum nokkurskonar kvikmyndasíu og áhugi Mána á Sólu kviknar ekki fyrr en hann áttar sig á líkindum hennar og Musidoru.

Kvikmyndin Blóðsugurnar fjallar um glæpagengi sem hrellir yfirstétt Parísarborgar og myrðir pá góðborgara sem peim tekst ekki að gera sér hliðholla. „París er á röngunni, óútreiknanleg og banvæn [...] Annar hver maður er í dulargervi, nafni og pjóðfélagsstöðu er aldrei að treysta - háborgarastéttin pekkir ekki sína eigin frá glæpamönnunum. “65 Hér má túlka blóðsugurnar sem afbyggjandi plágu sem kallast á við spænsku veikina. Vampírur pjóðsagna og bókmennta eru jafnframt smitberar blóðpyrstrar plágu. Pær sökkva tönnum sínum í hold manna (rjúfa mörk líkamans) til pess að drekka blóð peirra og stefna par með líkamsmörkum peirra í hættu. Lifi fórnarlambið af breytist pað gjarnan í vampíru. Líkaminn, líkt og Parísborg, er á „röngunni“- innra verður ytra og hver sem er getur

63 Sama rit, bls. 13.

64 Sjón, Mánasteinn, bls. 25.

65 Sama rit, bls. 40. 
borið veiruna með sér, líka góðborgarar Reykjavíkur. Úlfhildur Dagsdóttir bendir á að myndmál vampírunnar í Mánasteini vísi til kynhneigðar Mána pví vampírur gotnesku bókmenntahefðarinnar endurspegluðu iðulega ótta við „afbrigðilegar“" kynhneigðir. ${ }^{66}$

Aðdáun Mána á Blóðsugunum skýrist af utangarðsstöðu hans sjálfs. Blóðsugurnar fremja glæpina „af glaðbeittri ástríðu pess sem hefur sagt sig úr lögum við samborgara sína“. ${ }^{67}$ Aðeins sá sem tilheyrir plágunni getur gengið óhræddur um götur borgarinnar líkt og Máni gerir pegar ástandið er sem allra verst - pví hann upplifir sig nú pegar sem smitaðan einstakling. Frá fæðingu hefur Máni fengið pau skilaboð að hold hans og blóð (móðir hans) séu sjúk og purfi að einangra og hylja. Langömmusystir hans innrætir honum skömmina sem markar líf hans: „[...] hann mætti aldrei segja nokkurri sálu frá pví hvað kom fyrir mömmu hans og „aldrei, aldrei, aldrei“ að hann sjálfur hefði verið vistmaður á Holdsveikraspítalanum. “68 Hann einangrar sig pví af sjálfsdáðum til pess að purfa ekki að upplifa frekari höfnun. Hann tekur sér stöðu á „ósýnilega blettinum“69 og horfir á samferðafólk sitt úr fjarlægð. ${ }^{70}$

Austurríski sálgreinirinn Otto Rank rakti tilurð tvífaraminnisins í bókinni Tvífarinn: Rannsókn i sálgreiningu (Der Doppelgänger: Eine Psychoanalytische Studie). Rank bendir á að hugmyndin um tvífarann hafi komið fram á svipuðum tíma og hugmyndin um tilvist sálarinnar og að tvífarinn sé sálrænt frávarp sjálfsins sem óttast endalok dauðans. ${ }^{71}$ Skuggi er dæmi um frumstæða birtingarmynd tvífarans pví skugginn líkist manneskjunni sem honum varpar. Skugginn, eða tvífarinn, er trygging fyrir bví að sjálfið muni lifa af í einhverri mynd, pótt að líkami manneskjunnar deyi. ${ }^{72}$

66 Úlfhildur Dagsdóttir, Sjónsbók: Avintýrið um böfundinn, súrrealisma og sýnir, Reykjavík: JPV útgáfa, 2016, bls. 375-377.

67 Sjón, Mánasteinn, bls. 40.

68 Sama rit, bls. 124.

69 Sama rit, bls. 75.

70 Sjónin er eitt af fáum skynfærum sem tengja hann við umhverfi sitt, hann horfir á kvikmyndir, „hleður peim í sig“ og fylgist svo með umhverfi sínu í gegnum kvikmyndasíu. Heyrnin er reyndar líka mikilvæg, pví pannig pekkir hann vélarhljóð mótorhjólsins hennar Sólu eða bíls hugsanlegs viðskiptavinar. Skynfæri sem krefjast nálægðar, jafnvel snertingar eru sjaldnast virkjuð nema við samfarir.

71 Hér er ensk pýðing Harry Tucker Jr. notuð: Otto Rank, „Narcissism and the Double“, Essential Papers on Literature and Psychoanalysis, ritstj. Emanuel Berman, pýð. Harry Tucker Jr., New York: New York University Press, 1993, bls. 122-138, hér bls. 126.

72 Sama rit, bls. 129-130. 
Máni finnur sér pó ekki tvífara í Sólu vegna bess að hann óttast dauðann, heldur vegna pess að hann upplifir að hann eigi enga framtíð í samfélagi sem afneitar tilveru hans. Framtíðarleysi er ein birtingarmynd dauðabeygs og pví parfnast hann tvífara til pess að skapa sér nútíð og framtíð. Рað má segja að hann sé í einskonar tvöfaldri útlegð frá menningarlegum líkama sínum, fyrst sem sonur óhreinnar móður og síðar sökum óleyfilegrar kynhneigðar. Geir Svansson bendir á tengsl tvífarabókmennta og samkynhneigðar í greininni „Ósegjanleg ást: Hinsegin sögur og hinsegin fræði í íslensku samhengi“. Par bendir hann á að hræsni Viktoríutímabilsins í kynferðismálum hafi byggst á bælingu og kúgun sem leitt hafi til „eins konar geðklofa í tíðarandanum og endurspeglast í vissum skáldverkum tímabilsins “ ${ }^{73}$ Ólögmæti samkynja ástar gat af sér tvöfeldni par sem tvífarinn táknaði ósamræmanleika hins opinbera lífs og hins dulda lífs: „Hinar „dauðadæmdu tvífarabókmenntir“ [19. aldar] tjáðu ómöguleika pess að lifa einlægu samkynhneigðu líferni.“"74

Pótt Sóla tilheyri hópi góðborgara Reykjavíkur fylgir hún ekki hefðbundnum klæðnaði og venjum ungra kvenna. Hún peysir um á rauðu mótorhjóli í aðsniðnum leðursamfestingi sem minnir á heilgalla glæpakvendisins Irmu Vep. Hún málar sig á ögrandi hátt, varirnar blóðrauðar, húðin hvít og augun svartmáluð. Prátt fyrir að eiga hóp af vinum pá er hún ekki hrædd við að fara eigin leiðir og breyta í samræmi við eigin sannfæringu. Hún er í raun frávörpuð mynd af pví sem Máni sækist eftir að vera, en getur ekki sökum pess að líkami hans er samfélagslega óæskilegur. Sú Sóla Guðb- sem Máni dýrkar er persóna en ekki manneskja: „Hann veit að pað er í náttúru kvenna eins og Sólu Guðb- og Irmu Vep [...] að pær geta brugðið sér í púsund gervi og eru í senn „Allar konur“ og „Konan eina“ - jafnvel pegar pær eru í jakkafötum og með bindi."75 Jakkafataklædda konan birtist sem vísun í atriðið í Blóðsugunum par sem Irma klæðist einu af sínum fjölmörgu dulargervum. ${ }^{76}$ En vísunin kallast einnig á við drauminn par sem höfuð Mána er aðskilið frá líkama hans - sem er vísbending um klofning líkama og sjálfs.

73 Geir Svansson, „Ósegjanleg ást: Hinsegin sögur og hinsegin fræði í íslensku samhengi“, Skirnir 172 (haust)/1998, bls. 476-512, hér bls. 490.

74 Sama rit, bls. 492.

75 Sjón, Mánasteinn, bls. 39.

76 Louis Feuillade, „Les Yeux qui fascinent“, Les Vampires [6. páttur], kvikmynd, leikstjóri Louis Feuillade, Frakkland, Gaumont, 1915, sótt 15. mars 2018 af https:// archive.org/details/lesVampires1915Episode6-hypnoticEyes 
Раð er aðeins í peirri upplausn sem ríkir meðan veikin heltekur líkamann (og samfélag Reykjavíkur) að Máni getur sameinað sjálfin tvö. Í óráði veikindanna, pegar hann dreymir að hann sundri líkama sínum, leiðir upplausnin til pess að Máni verður að skugga og hliðarsjálfið Sóla kemur og hirðir pað sem eftir er af líkama Mána og bókstaflega klæðir sig í hann. Dagný Kristjánsdóttir segir: „Pau renna saman, tvö kyn í

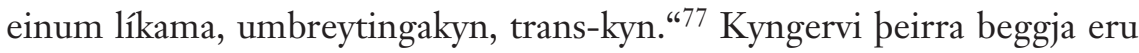
á mörkum og mætti segja að pau séu vífguma (e. androgynous) í raunheiminum eða að minnsta kosti kynsegin (e. non-binary eða gender queer), en renni saman í transkyn í óráðsdraumi veikindanna. Pó framsetning Sólu á kyngervi sínu sé oft á tîðum skopstæling kvenleika (undirstrikuð augu og varir, pröngur samfestingur sem dregur fram kvenlegar línur, „allt sem honum er ætlað að hylja“78) pá samræmist hegðun hennar og „karllæg“ áhugamál hugmyndinni um Nýju konuna (e. the New Woman). ${ }^{79}$ Pannig er hún allt í senn, „Allar konur“ og „Konan eina“. Athygli vekur að í verkinu ber hvergi á gagnrýni á klæðaburð eða áhugamál Sólu. Áhugi hennar á mótorhjólum pykir ekkert tiltökumál og hún fær óáreitt að vinna í hjólinu á verkstæði Bifreiðafjelags Reykjavíkur í skiptum fyrir prif á leigubílum. Máni finnur sig hinsvegar ekki innan æskulýðsstarfs Væringjanna par sem „[a]llt gekk út á að vera vaskur sveinn og besti vinur foringjanna sem leiddu hópinn í skátaæfingum sem ætlað var að efla karlmennsku peirra og andlega burði“. ${ }^{80}$ Máni hefur meiri áhuga á búningnum sem fylgir Væringjastarfinu pví búningurinn gerir honum kleift að líða eins og „hann væri einhver annar“ ${ }^{81}$ Mikilvægi karlmennskuímynda í sjálfstæðisbaráttunni gæti verið hugsanleg skýring á pví hvers vegna samfélagið leggur meiri áherslu á að viðhalda karlmennskuímyndum en hugmyndum um kvenleika. Sigríður Matthíasdóttir segir að „[p]jóðernisorðræðan [...]

77 Dagný Kristjánsdóttir, „Mánasteinn í grimmdarleikhúsi spænsku veikinnar“, bls. 479.

78 Sjón, Mánasteinn, bls. 12.

79 Nýja konan kom fram á sjónarsviðið undir lok síðustu aldar í Evrópu og er hún talin til brautryðjenda kvenfrelsishreyfingarinnar. Nýja konan véfengdi viktorískar hugmyndir um kvenleika og hlutverk kvenna og pótti íhaldssömum hún færa sig full mikið inn á svið karla. Sjá Elaine Showalter, Sexual Anarchy: Gender and Culture at the Fin de Siècle, London: Bloomsbury, 1991, bls. 3 og bls. 38-40.

80 Sjón, Mánasteinn, bls. 22-23.

81 Sama rit, bls. 23 
virðist að miklu leyti hafa látið konur og stöðu peirra liggja á milli hluta“82 og að pjóðernisstefnan hafi verið mjög karllæg. En skortur á gagnrýni á klæðaburð og hegðun Sólu gæti líka skýrst af pví að sjónarhornið er að miklu leyti bundið við Mána og pví fær lesandinn ekki að skyggnast inn í hugarheim Sólu og kynnast peim viðhorfum sem hún mætir pegar hún brýtur gegn samfélagslegum venjum.

\section{Að lokum}

Eins og gerð hefur verið grein fyrir leitast samfélagið við að skapa ásýnd hreinleika og samfellu. En innrás spænsku veikinnar afhjúpar að pað er ekki eins slétt og fellt og pað vill sýnast. Spænska veikin er ógn sem virðir flest mæri að vettugi. Farsóttin leggst jafnt á háa sem lága og purrkar út (um tíma) stigveldi borgarsamfélagsins. Sjúkdómurinn færir einnig vessa líkamans upp á yfirborðið og afbyggir par með líkamsmörk sem sögð eru heil og óhagganleg. Sökum pess að samfélagið viðheldur mörkum sínum í gegnum eftirlit og ögun líkama pegna sinna er ljóst að formgerð samfélagsins er jafn fljótandi og mörk líkamans. Frávik frá hinum „heilbrigða“, gagnkynhneigða líkama skapa óeiningu innan heildarinnar og pví leitast samfélagið við að fela slík frávik. Aðalpersóna Mánasteins, Máni Steinn, er á skjön við pær karlmennskuímyndir sem samfélagið hampar og pví parf að senda hann úr landi til pess að endurheimta yfirbragð heilsteyptrar pjóðar. Í verkinu eru afbyggjandi eiginleikar spænsku veikinnar settir í samhengi við kynhneigð Mána. Samanburðurinn hefur margskonar virkni: Í aðra röndina undirstrikar hann sjúkdómsvæðingu samkynhneigðar sem átt hafði sér stað á meginlandi Evrópu á 19. öld og ótta við hverskyns smit sem ber með sér hugmyndir eða hegðun sem talin var framandi íslenskum veruleika. Í hina röndina er samanburðurinn til pess fallinn að afhjúpa tilbúnar skilgreinar og óstöðug mörk samfélagsins og peirra menningarfyrirbæra sem pví tilheyra. Líkami drengsins sem aldrei var til sviptir pannig hulunni af óreiðuástandi samfélags í mótun.

82 Sigríður Matthíasdóttir, Hinn sanni Íslendingur: Pjóðerni, kyngervi og vald á Íslandi 1900-1930, Reykjavík: Háskólaútgáfan, 2004, bls. 219. 


\section{ÚTDRÁTTUR}

\section{Líkami drengsins sem aldrei var til}

Um samband samfélags og líkama í óreiðuástandi spænsku veikinnar í Mánasteini eftir Sjón

Skáldsagan Mánasteinn: Drengurinn sem aldrei var til (2013) eftir Sjón segir frá premur viðburðaríkum mánuðum í lífi drengsins Mána Steins haustið 1918. Á pessum stutta tíma gýs Katla, spænska veikin gengur yfir og Ísland öðlast fullveldi frá Dönum. Í greininni er líkamsorðræða Mánasteins skoðuð með hliðsjón af kenningum Judith Butler, Mary Douglas og Michel Foucault er lúta að líkamanum sem menningarlegri smíð. Samkvæmt Douglas eru hættusvæði líkamans beintengd hættusvæðum samfélagsins og allt pað sem ógnar mörkum samfélagsheildarinnar er talið félagsleg mengun (e. social pollution). Foucault fetar svipaðar slóðir í alsæiskenningu sinni, en samkvæmt henni viðheldur borgarsamfélagið formgerð sinni með eftirliti og ögun líkama pegna sinna. Máni Steinn er samkynhneigður og er líkami hans pví á skjön við hugmyndir pess tíma um hvað telst heilsteyptur og heilbrigður líkami. Frávik frá hinum „heilbrigða“, gagnkynhneigða líkama skapar óeiningu innan heildarinnar og pví leitast samfélagið við að útskúfa Mána. En koma spænsku veikinnar til Reykjavíkur umturnar stigveldi samfélagsins og afbyggir viðteknar hugmyndir um líkamann. Aðgreining heilbrigðra og smitaðra purrkast út og líkaminn verður vettvangur par sem ósættanlegar andstæður renna saman. Í óreiðuástandi spænsku veikinnar verða landamæri líkamans óskýr og mörk samfélagsins verða að sama skapi fljótandi.

Lykilorð: Spænska veikin, plágur, Sjón, Mánasteinn: Drengurinn sem aldrei var til, mörk líkamans, samfélag, hinsegin/samkynhneigð, félagsleg mengun, Reykjavík

\section{A B S T RACT}

\section{The body of the boy who never was}

The interchangeable relationship between the body and society during the Spanish flu in Moonstone by Sjón

Moonstone: The Boy Who Never Was (Mánasteinn: Drengurinn sem aldrei var til, 2013) by Sjón tells of three eventful months in the life of Máni Steinn in the fall of 1918. In this short period the volcano Katla erupts, the Spanish flu rages and Iceland regains its sovereignty from Denmark. Building on Judith Butler's, Mary Douglas's and Michel Foucault's theories regarding the body as a cultural construct, this article 
focuses on body discourse as presented in Moonstone. According to Douglas there is a direct link between boundaries of the body and boundaries of society. Everything that endangers the stability of society's boundaries is considered social pollution. Foucault's theory on panopticism likewise identifies surveillance and discipline of citizens' bodies as means of maintaining society's social structure. Because Máni Steinn is queer, his body is considered abnormal according to the period's definitions on what constitutes a healthy and stable body. Aberrations from the „healthy“, heterosexual body creates divergence within society's fabric. To regain the appearance of a „pure“ society Máni needs to be hidden or banished from it. Yet the arrival of the Spanish flu to Reykjavík deconstructs conventional definition of the body and unravels the social hierarchy. The distinction between the healthy and the infected is obliterated, as the body becomes a site where irreconcilable opposites merge. During the turmoil of the Spanish flu boundaries of the body become as unstable as society's boundaries become fluent.

Keywords: Spanish flu, plagues, Sjón, Moonstone: The Boy Who Never Was, boundaries of the body, society, queer, social pollution, Reykjavík.

\author{
Kristín María Kristinsdóttir \\ Bókmenntafræðingur \\ Pingholtsstræti 26 \\ IS-101 Reykjavík, Ísland \\ stinam@gmail.com
}

